\title{
Study on Properties of Self-Compacting Geopolymer Concrete
}

\author{
Ashraf Mohamed Henigal ${ }^{1}$, Mohamed Amin Sherif ${ }^{2}$, and \\ Hassan Hamouda Hassan ${ }^{3}$ \\ 1, 2, 3 (Civil Construction Dept., Faculty of Industrial Education/Suez University, Suez, Egypt)
}

\begin{abstract}
The sustainable production ofself-compacting geopolymer concrete (SCGC) is an environment friendly concrete which has lower carbon footprint as compared to that of conventional concrete. This paper presents the study of the fresh and mechanical properties for self-compacting geopolymer concrete, In addition to the physical properties. Some parameters were studied such as varying the molarity of sodium hydroxide from $8 M$ to $14 M$, ratio of sodium hydroxide to sodium silicate solution were between (1:2 to 1:2.75), alkaline solution to fly ash ratio, extra water ratio, fly ash content was between $400 \mathrm{Kg} / \mathrm{m}^{3}$ to $500 \mathrm{Kg} / \mathrm{m}^{3}$, curing time, and curing temperature. Compressive strength test was carried out at the ages of 3, 7, 28, and 91 days. The others mechanical and physical properties tests were carried out at the age 28 days. The Increase of sodium hydroxide molarity slightly reduces fresh properties of self-compacting geopolymer concrete. The mechanical properties of self-compacting geopolymer concrete are only a fraction of the compressive strength, as in the case of self-compacting concrete (SCC) with Portland cement. Increasing in the test results of physical properties adversely affect it's the mechanical properties of self-compacting geopolymer concrete. Heat-cured self-compacting geopolymer concrete undergoes very low drying shrinkage compared to that of self-compacting concrete with ordinary Portland cement.
\end{abstract}

Keywords: Geopolymer, Self-Compacting, Fresh Properties, Compressive Strength, Dry Shrinkage

\section{Introduction}

Concrete is one of the most far used construction materials in the world. Portland cement (PC); an essential constituent of concrete is not an environmentally friendly material. The production of PC not only depletes significant amount of natural resources but also liberates a considerable amount of carbon dioxide $\left(\mathrm{CO}_{2}\right)$ and other greenhouse gases in to the atmosphere as a result of decarbonation of limestone and the combustion of fossil fuels. Self-compacting geopolymer concrete (SCGC) is relatively a new concept and can be regarded as the most revolutionary development in the field of concrete technology. (SCGC) is an innovative type of concrete that does not require vibration for placing it and can be produced by complete elimination of ordinary Portland cement [1].

The use of geopolymer technology in making concrete has environmental benefit as it could reduce the $\left(\mathrm{CO}_{2}\right)$ emission to the atmosphere up to $80 \%$ compared to (OPC) concrete [2].

So, to reduce greenhouse gas emissions, efforts are needed to develop environmentally friendly construction materials. The contribution of ordinary Portland cement (OPC) production worldwide to greenhouse gas emissions is estimated to be approximately 1.35 billion tons annually or approximately $7 \%$ of the total greenhouse gas emissions to the earth's atmosphere. Also, it has been reported that many concrete structures, especially those built in corrosive environments, start to deteriorate after 20 to 30 years, even though they have been designed for more than 50 years of service life. In geopolymer concrete, a by-product material rich in silicon and aluminum, such as low-calcium fly ash, is chemically activated by a high-alkaline solution to form a paste that binds the loose coarse and fine aggregates and other unreacted materials in the mixture [3].

To preserve the global environment from the impact of cement production, it is imperative to search and explore new possibilities to develop a concrete material that is more environmentally friendly as well as an efficient construction material to replace conventional Portland cement concrete [4].

According to Nuruddin et al. [5] self-compacting geopolymer concrete (SCGC) can be considered as an advanced and innovative construction material in the concrete technology. As the name implies, it does not need any compacting efforts to achieve full compaction and utilizes fly ash together with alkaline solution and superplasticizer as a binder for matrix formation and strength.

According to Omar Mohamed [6] indicated that the heat-cured fly ash-based geopolymer concrete undergoes very low drying shrinkage from ordinary Portland cement concrete.

The main aim of this research study on fresh states, mechanical and physical properties of self-compacting geopolymer concrete SCGC by utilizing locally available constituent materials. 


\subsection{Materials for concrete mixture}

\section{Experimental work}

\subsubsection{Fly ash}

Fly ash is an industrial by-product of coal-fired power stations; the fly ash used in this research is classified as class F fly ash according to the requirement of ASTM C618 Class F [7]. The chemical composition of fly ash as determined by XRF is given in Table 1 .

\subsubsection{Cement}

In this study, Ordinary Portland Cement (OPC) CEM I 42.5 N. produced by EL-Suez cement company in Egypt was used as binder to produce of self-compacting concrete (SCC). Testing of cement was carried out as the Egyptian Standard Specifications ESS 4756-1/2009 [8], with the specific gravity of 3.15 was used.

Table 1Chemicalcompositionofflyashas determinedby XRF

\begin{tabular}{|l|l|l|}
\hline Oxide & By Mass \% & $\begin{array}{l}\text { Requirements As Per ASTM C } \\
\text { 618 Class F }\end{array}$ \\
\hline Silicon dioxide $\left(\mathrm{SiO}_{2}\right)$ & 61.10 & ----- \\
\hline Aluminum oxide $\left(\mathrm{Al}_{2} \mathrm{O}_{3}\right)$ & 28.60 & ----- \\
\hline Ferric oxide $\left(\mathrm{Fe}_{2} \mathrm{O}_{3}\right)$ & 3.20 & ---- \\
\hline Total $\left(\mathrm{SiO}_{2}+\mathrm{Al}_{2} \mathrm{O}_{3}+\mathrm{Fe}_{2} \mathrm{O}_{3}\right)$ & 92.90 & Min. 70\% \\
\hline Calcium oxide $(\mathrm{CaO})$ & 1.40 & ----- \\
\hline Magnesium oxide $(\mathrm{MgO})$ & 1.30 & Max. 5\% \\
\hline Sulphur trioxide $\left(\mathrm{SO}_{3}\right)$ & 1.06 & Max. 5\% \\
\hline Potassium oxide $\left(\mathrm{K}_{2} \mathrm{O}\right)$ & 1.17 & ----- \\
\hline Titanium dioxide $\left(\mathrm{TiO}_{2}\right)$ & 0.35 & ---- \\
\hline Sodium oxide $\left(\mathrm{Na}_{2} \mathrm{O}\right)$ & 0.76 & Max. 1.5\% \\
\hline Total Chlorides $(\mathrm{Cl})$ & 0.03 & Max. 0.05\% \\
\hline Loss on Ignition $(\mathrm{LOI})$ & 1.13 & Max. 6\% \\
\hline
\end{tabular}

\subsubsection{Aggregates}

Fine aggregate used in this experimental work was natural siliceous sand from (Suez area, Egypt), clean and rounded fine aggregate with size 0.15 to $5 \mathrm{~mm}$, a specific gravity of 2.67 , a bulk unit weight of 1686 $\mathrm{Kg} / \mathrm{m}^{3}$, and fineness modulus of 2.76 . Three types of coarse aggregates were used in this research. These types are local crushed limestone (dolomite), natural gravel, and crushed granite. The first type of local crushed limestone (dolomite) with a specific gravity of 2.68 , a bulk unit weight of $1619 \mathrm{Kg} / \mathrm{m}^{3}$, and maximum nominal size of $10 \mathrm{~mm}$ was obtained from (Attaka Quarries, EL Suez area, Egypt), according to the requirement of ESS 1109/2002 [9]. The second type of coarse aggregates used in this research is natural gravel with a specific gravity of 2.50 , a bulk unit weight of $1537 \mathrm{Kg} / \mathrm{m}^{3}$, and maximum nominal size of $9 \mathrm{~mm}$ was obtained from (Eleyn Elskhna, EL Suez area, Egypt). The third type of crushed granite was obtained from (Aswan area, Egypt) with a specific gravity of 2.60 , a bulk unit weight of $1564 \mathrm{Kg} / \mathrm{m}^{3}$, and maximum nominal size of $9 \mathrm{~mm}$ was investigated as well.

\subsubsection{Limestone powder}

Limestone powder (LSP) was locally produced in Egypt having a specific gravity of 2.71, a color of white and bulk unit weight of $1418 \mathrm{Kg} / \mathrm{m}^{3}$ was used.

\subsubsection{Silica fume}

In this research study, silica fume (SF) was locally produced in Egypt having a silica content of $96.5 \%$, a specific gravity of 2.15 , a color of light gray, a bulk unit weight of $392 \mathrm{Kg} / \mathrm{m}^{3}$ and specific surface area of $20000 \mathrm{~cm}^{2} / \mathrm{gm}$ was used.

\subsubsection{Superplasticizer}

In order to achieve superior workability and required flowability of the fresh concrete, there is a commercially available superplasticizer named as Sika Egypt Viscocrete-3425. It meets the requirements for superplasticizer according to ASTM-C-494 Type G and BS EN 934 part 2: 2001, with a specific gravity of 1.08 and a color of clear liquid.

\subsubsection{Alkaline solution}

In geopolymer synthesis, alkaline solution plays an important role. In this study, a combination of sodium hydroxide and sodium silicate was chosen as the alkaline liquid. Sodium Silicate Solution (SSS) was obtained from (Suez area, Egypt). $\left(\mathrm{Na}_{2} \mathrm{O}=14.6 \%, \mathrm{SiO}_{2}=29.5 \%\right.$ and water $=55.86 \%$ by mass), a specific gravity 1.54 was used in this experimental work. Sodium Hydroxide Solution (SHS), analytical grade sodium hydroxide in flake form (NaOH with $98-99 \%$ purity), was obtained from (6th of October City, Egypt). The solids must be dissolved in water to make a solution with the required concentration. It is strongly recommended that the sodium hydroxide solution must be prepared 24 hours prior to use. The concentration of sodium 
hydroxide solution can vary in the range between 8 Molar and 14 Molar; however, 12 Molar solution is adequate for most applications. The mass of $\mathrm{NaOH}$ solids in a solution varies depending on the concentration of the solution. For instance, $\mathrm{NaOH}$ solution with a concentration of 12 Molar consists of 12 x $40=480$ grams of $\mathrm{NaOH}$ solids per liter of the water, where 40 is the molecular weight of $\mathrm{NaOH}$. The mass of $\mathrm{NaOH}$ solids was measured as 361 grams per $\mathrm{kg}$ of $\mathrm{NaOH}$ solution and 639 grams of water with a concentration of 12 Molar.

\subsubsection{Water}

Specified amount of extra water was also used in the mix. The ordinary potable water available in the concrete laboratory was used for this purpose.

\subsection{Mix proportion}

This experimental study program was designed to achieve the research objectives of the study. The program consists of three mixtures of self compacting concrete were (A, B, andC) with Portland cement was $400 \mathrm{Kg} / \mathrm{m}^{3}, 450 \mathrm{Kg} / \mathrm{m}^{3}$, and $500 \mathrm{Kg} / \mathrm{m}^{3}$, respectively. The coarse aggregate type of dolomite was used, fine to coarse aggregates ratios were (45\%: $55 \%$ ). Limestone powder, silica fume, and superplasticizer dosage ratios were $15 \%, 10 \%$, and $4 \%$ respectively, as addition to cement content by weight in three mixtures. The water to cementitious materials for mixtures $\mathrm{A}, \mathrm{B}, \mathrm{C}$ was $(0.33,0.32$, and 0.30 , respectively). Furthermore, thirty-two mixtures of SCGC were prepared to assess the fresh state and studying the influence of various parameters on the compressive strength at several cases curing $(3,7,28$, and 91 days) and splitting tensile strength, flexural strength, bond strength, and modulus of elasticity at age 28 days for all mixtures. Only sixteen mixtures of them were utilized to assess testing the water absorption, water permeability, and drying shrinkage. The details of SCGC mixtures are given in Table 2.

Table2 Mixproportionsforself-compactinggeopolymerconcrete

\begin{tabular}{|c|c|c|c|c|c|c|c|c|c|c|c|c|}
\hline \multirow{3}{*}{$\begin{array}{l}\text { Mix } \\
\text { Code }\end{array}$} & \multirow{3}{*}{$\begin{array}{c}\begin{array}{c}\text { Fly } \\
\text { Ash }\end{array} \\
\mathrm{Kg} / \mathrm{m}^{3}\end{array}$} & \multirow{3}{*}{$\begin{array}{c}\text { F.Agg } \\
\% \\
\end{array}$} & \multirow{2}{*}{\multicolumn{2}{|c|}{ C.Agg }} & \multirow{2}{*}{\multicolumn{2}{|c|}{$\begin{array}{l}\text { Sodium } \\
\text { Hydroxide }\end{array}$}} & \multirow{3}{*}{$\begin{array}{c}\text { Sodium } \\
\text { Silicate } \\
\text { Ratio }\end{array}$} & \multirow{3}{*}{$\begin{array}{c}\text { Alkaline/Fly } \\
\text { Ash } \\
\text { Ratio }\end{array}$} & \multirow{3}{*}{$\begin{array}{c}\text { Super } \\
\text { Plasticizer }\end{array}$} & \multirow{3}{*}{$\begin{array}{c}\text { Extra } \\
\text { Water } \\
\%\end{array}$} & \multicolumn{2}{|c|}{ Curing } \\
\hline & & & & & & & & & & & \multirow{2}{*}{$\begin{array}{l}\text { Time } \\
\text { Hours }\end{array}$} & \multirow{2}{*}{$\frac{\text { Temp. }}{{ }^{\circ} \mathrm{C}}$} \\
\hline & & & Type & $\%$ & Ratio & Mol. & & & & & & \\
\hline M1 & 400 & 40 & Dolomite & 60 & 1 & 12 & 2.5 & 0.5 & 6 & 12 & 48 & 70 \\
\hline M2 & 400 & 45 & Dolomite & 55 & 1 & 12 & 2.5 & 0.5 & 6 & 12 & 48 & 70 \\
\hline M3 & 400 & 50 & Dolomite & 50 & 1 & 12 & 2.5 & 0.5 & 6 & 12 & 48 & 70 \\
\hline M4 & 400 & 45 & Dolomite & 55 & 1 & 12 & 2 & 0.5 & 6 & 12 & 48 & 70 \\
\hline M5 & 400 & 45 & Dolomite & 55 & 1 & 12 & 2.25 & 0.5 & 6 & 12 & 48 & 70 \\
\hline M6 & 400 & 45 & Dolomite & 55 & 1 & 12 & 2.75 & 0.5 & 6 & 12 & 48 & 70 \\
\hline M7 & 400 & 45 & Dolomite & 55 & 1 & 8 & 2.5 & 0.5 & 6 & 12 & 48 & 70 \\
\hline M8 & 400 & 45 & Dolomite & 55 & 1 & 10 & 2.5 & 0.5 & 6 & 12 & 48 & 70 \\
\hline M9 & 400 & 45 & Dolomite & 55 & 1 & 14 & 2.5 & 0.5 & 6 & 12 & 48 & 70 \\
\hline $\mathrm{M} 10$ & 400 & 45 & Dolomite & 55 & 1 & 12 & 2.5 & 0.3 & 6 & 12 & 48 & 70 \\
\hline M11 & 400 & 45 & Dolomite & 55 & 1 & 12 & 2.5 & 0.4 & 6 & 12 & 48 & 70 \\
\hline M12 & 400 & 45 & Dolomite & 55 & 1 & 12 & 2.5 & 0.5 & 5 & 12 & 48 & 70 \\
\hline M13 & 400 & 45 & Dolomite & 55 & 1 & 12 & 2.5 & 0.5 & 7 & 12 & 48 & 70 \\
\hline M14 & 400 & 45 & Dolomite & 55 & 1 & 12 & 2.5 & 0.5 & 6 & 10 & 48 & 70 \\
\hline M15 & 400 & 45 & Dolomite & 55 & 1 & 12 & 2.5 & 0.5 & 6 & 14 & 48 & 70 \\
\hline M16 & 400 & 45 & Dolomite & 55 & 1 & 12 & 2.5 & 0.5 & 6 & 16 & 48 & 70 \\
\hline M17 & 400 & 45 & Dolomite & 55 & 1 & 12 & 2.5 & 0.5 & 6 & 12 & 24 & 70 \\
\hline M18 & 400 & 45 & Dolomite & 55 & 1 & 12 & 2.5 & 0.5 & 6 & 12 & 72 & 70 \\
\hline M19 & 400 & 45 & Dolomite & 55 & 1 & 12 & 2.5 & 0.5 & 6 & 12 & 48 & 60 \\
\hline $\mathrm{M} 20$ & 400 & 45 & Dolomite & 55 & 1 & 12 & 2.5 & 0.5 & 6 & 12 & 48 & 80 \\
\hline M21 & 450 & 45 & Dolomite & 55 & 1 & 12 & 2.5 & 0.5 & 5 & 12 & 48 & 70 \\
\hline $\mathrm{M} 22$ & 450 & 45 & Dolomite & 55 & 1 & 12 & 2.5 & 0.5 & 6 & 12 & 48 & 70 \\
\hline M23 & 450 & 45 & Dolomite & 55 & 1 & 12 & 2.5 & 0.5 & 7 & 12 & 48 & 70 \\
\hline M24 & 500 & 45 & Dolomite & 55 & 1 & 12 & 2.5 & 0.5 & 5 & 12 & 48 & 70 \\
\hline M25 & 500 & 45 & Dolomite & 55 & 1 & 12 & 2.5 & 0.5 & 6 & 12 & 48 & 70 \\
\hline M26 & 500 & 45 & Dolomite & 55 & 1 & 12 & 2.5 & 0.5 & 7 & 12 & 48 & 70 \\
\hline M27 & 400 & 45 & Gravel & 55 & 1 & 12 & 2.5 & 0.5 & 6 & 12 & 48 & 70 \\
\hline M28 & 450 & 45 & Grave1 & 55 & 1 & 12 & 2.5 & 0.5 & 6 & 12 & 48 & 70 \\
\hline M29 & 500 & 45 & Gravel & 55 & 1 & 12 & 2.5 & 0.5 & 6 & 12 & 48 & 70 \\
\hline M30 & 400 & 45 & Granite & 55 & 1 & 12 & 2.5 & 0.5 & 6 & 12 & 48 & 70 \\
\hline M31 & 450 & 45 & Granite & 55 & 1 & 12 & 2.5 & 0.5 & 6 & 12 & 48 & 70 \\
\hline M32 & 500 & 45 & Granite & 55 & 1 & 12 & 2.5 & 0.5 & 6 & 12 & 48 & 70 \\
\hline
\end{tabular}

\subsection{Details of testing procedure}

Filling ability, passing ability and resistance to segregation can be examined by the test methods. The European Guidelines EFNARC has proposed different test methods to characterize an SCC mix. Test methods and fresh state properties along with their recommended values given by EFNARC [10]. Compression test at age $3,7,28$, and 91 days is carried out on; $100 \times 100 \times 100 \mathrm{~mm}$ cubes, splitting tensile strength test at age 28 days is carried out on; $150 \times 300 \mathrm{~mm}$ cylinder, flexural strength test at age 28 days is carried out on; $100 \times 100 \times 500$ $\mathrm{mm}$ prisms, bond strength test at age 28 days is carried out on; $150 \times 300 \mathrm{~mm}$ cylinder, static modulus of elasticity at age 28 days is carried out on; $150 \times 300 \mathrm{~mm}$ cylinder, water permeability test at age 28 days is carried out on; $150 \times 150 \mathrm{~mm}$ cylinder, water absorption test at age 28 days is carried out on; $100 \times 100 \times 100 \mathrm{~mm}$ cubes, and test specimens for drying shrinkage test were $25 \times 25 \times 285 \mathrm{~mm}$ prisms at age $3,7,14,21,28,56$, and 91 days. 


\subsection{Mixing procedure}

The concrete mixing procedure consists of dry and wet mixing. Self-compacting concrete SCC was mixed efficiently in a concrete drum mixer. The constituents were mixed in dry state for about three minutes to ensure the uniformity of the mix. Mixing water and superplasticizer were added gradually and simultaneously during mixing. All contents were mechanically mixed for about four extra minutes. The solid components of SCGC, i.e. the fly ash and the fine and coarse aggregates, were dry mixed in the pan mixer for about three minutes. The liquid part of the mixture, i.e. the sodium silicate solution, the sodium hydroxide solution, extra water and the superplasticizer, were premixed thoroughly and then added to the dry mixture. The wet mixing was done for four minutes. It was believed that the chemical reaction between alkaline solution, superplasticizer and water took place and the reaction played an important role in giving the required fresh state for SCC and SCGC and compressive strength of hardened concrete. The fresh state of SCC and SCGC had a flowing consistency and with high tendency of filling ability, passing ability and resistance to segregation.

\subsection{Casting and curing of test specimens}

After mixing and assessing the necessary fresh properties as guided by EFNARC, the fresh concrete was then filled into steel moulds and allowed to fill all the spaces of the moulds by its own self weight without any compacting efforts. After casting, the SCC specimens were cured at water curing. Whereas the SCGC specimens were put in an oven at different curing temperatures of $\left(60^{\circ} \mathrm{C}, 70{ }^{\circ} \mathrm{C}\right.$, and $\left.80{ }^{\circ} \mathrm{C}\right)$, and different curing times of (24, 48, and 72 hours). The oven curing was followed by post curing by putting the specimens at average room temperature of $24^{\circ} \mathrm{C}$ for one day stabilization period. The oven curing followed by post curing was adopted in this research to accelerate geopolymerization process at elevated temperature and to enhance the mechanical and physical properties performance. The reported of testing the mechanical and physical properties is the average of three specimens. The test specimens were then left at average room temperature of $24^{\circ} \mathrm{C}$ until the specified days of testing.

\section{Test results and discussion}

\subsection{Fresh state tests of SCC and SCGC}

To achieve the fresh state properties for each mix slump flow, slump flow at $\mathrm{T} 50 \mathrm{~cm}, \mathrm{~V}$-funnel at T0, V-funnel at T5 minutes, L-Box (H2/H1), J-Ring, GTM screen stability, and air content tests were completed. Every one of the tests was performed by taking after The European Rules for SCC, [10]. The test consequences of fresh state properties are exhibited in Table 3.

\subsubsection{Effect of cement content on the fresh state properties}

Table 3 demonstrates the impact of concrete substance on the (SCC) mixtures with Portland cement. It is for the most part acknowledged that the greater cement content in a concrete mixture, the more paste/coarse aggregate proportion at a given mix proportioning. The three basic fresh properties required by SCC are Filling Ability, Passing Ability and Segregation Resistance. Test comes about showed that, the utilization of $400 \mathrm{~kg} / \mathrm{m}^{3}$ to $500 \mathrm{~kg} / \mathrm{m}^{3}$ of cement content gave sensible aftereffects of fresh concrete properties.

\subsubsection{Effect of coarse to fine aggregate ratio on the fresh state properties}

The test outcomes appeared in Table 3 demonstratesthe variety in coarse to fine aggregate ratio were between (60\%:40\%, 55\%:45\%, and 50\%:50\%)for mixtures M1, M2, and M3respectively, had somewhat impact on the new properties of (SCGC).Slump flow for every one of the mixtures was inside the (EFNARC) scope of 650-800 mm. A greatest slump flow value of $710 \mathrm{~mm}$ was accomplished for a mixture having coarse to fine aggregate ratio as (50\%:50\%).Expanding the coarse to fine aggregate ratio were between (60\%:40\%, 55\%:45\%, and 50\%:50\%) the consistency of the arrangement was expanded. Thus, the flow of the concrete was diminished up to $7.60 \%$, which might be ascribed to the expansion of increasing the fine to coarse aggregate ratio.

\subsubsection{Effect of alkaline solution to fly ash ratio on the fresh state properties}

The test results shown in Table 3 indicate that the variation in alkaline solution to fly ash ratio were between $(0.3,0.4$, and 0.5$)$ for mixtures M10, M11, and M2respectively, the J-Ring test shows the results of the quantitative measurements and visual observations showed that it gave a good passing ability and the J-Ring value especially at 0.5 alkaline solution to fly ash ratio for mixture M2

as compared to the other mixtures, was within the permissible limits of $0-10 \mathrm{~mm}$ given by (EFNARC). It was observed that, for concrete mixture containing higher alkaline solution to fly ash ratio, the flowability and passing ability of fresh concrete was increased as a result, J-Ring value was also reduced up to $50 \%$ due to the increase in alkaline solution to fly ash ratio lead to enhance the flowability and passing ability.

\subsubsection{Effect of variation of(SHS) to (SSS) ratio on the fresh state properties}

The test results shown in Table 3 demonstrate that the variety of sodium hydroxide to sodium silicate proportion solution were between $(1: 2,1: 2.25,1: 2.5$, and 1:2.75) for mixtures M4, M5, M2, and M6 respectively. Test comes about $\mathrm{T}_{50} \mathrm{~cm}$ demonstrates a most minimal slump flow time (2 seconds) which recorded for mixture M4 containing a proportion of sodium hydroxide to sodium silicate solution (1:2), was 
diminished up to $33.3 \%$ when contrasted with alternate blends. Expanding the proportion of sodium hydroxide to sodium silicate solution improves the consistency because of that high rate of $\mathrm{Na}_{2} \mathrm{SiO}_{3} / \mathrm{NaOH}$ which in part prompts quickened disintegration of the strong materials and gave more durable, ease, and flowability of (SCGC) mixtures.

\subsubsection{Effect ofsodium hydroxide molarities on the fresh state properties}

Table 3 demonstrates the molarity variety in sodium hydroxide from $8 \mathrm{M}$ to $14 \mathrm{M}$ for mixtures M7, M8, M2, and M9 had somewhat impact on the new properties of (SCGC). The consequences of the quantitative estimations and visual perceptions demonstrated that all the four blends had great passing ability and the J-Ring an incentive for every one of the mixtures was inside the allowable furthest reaches of 0-10 mm given by (EFNARC). A most minimal estimation of $4 \mathrm{~mm}$ was accomplished for the mixture containing $8 \mathrm{M}$ sodium hydroxide molarity. Expanding the molarity of sodium hydroxide, the flowability and passing ability of fresh concrete were lessened up to $50 \%$ which ascribed to the low rate of water-to-geopolymer solids proportion with the increase in molarity of sodium hydroxide subsequently; J-Ring quality was likewise expanded.

\subsubsection{Effect of fly ash content on the fresh state properties}

Table 3 demonstrates the consequences of variety of fly ash content that is between $(400,450$, and 500 $\mathrm{Kg} / \mathrm{m}^{3}$ ) for mixtures (M12, M21, and M24) with 5\% superplasticizer dose, (M2, M22, and M25) with 6\% superplasticizer dose, and (M13, M23, and M26) with 7\% superplasticizer dosage on the new properties of (SCGC) mixtures. Also, the J-Ring test demonstrates the consequences of the quantitative estimations and visual perceptions demonstrated that it gave a decent passing ability and the J-Ring esteem particularly at $500 \mathrm{Kg} / \mathrm{m}^{3}$ fly powder content with 7\% superplasticizer dose for mixture M26 when contrasted with alternate mixtures, was inside the admissible furthest reaches of 0-10 mm given by (EFNARC). It was noticed that for concrete mixtures containing higher fly ash content, the flowability and passing ability of fresh concrete was expanded. Therefore, J-Ring value was additionally lessened up to $33.3 \%$ due to the expansion in fly ash content with higher SP dose prompt deflocculation and scattering of binder particles to improve the flowability and passing ability.

Table 3Fresh state of test results for SCCand SCGC

\begin{tabular}{|c|c|c|c|c|c|c|c|c|}
\hline \multirow{3}{*}{$\begin{array}{l}\text { Mix } \\
\text { Code }\end{array}$} & \multicolumn{8}{|c|}{ Fresh state of test results } \\
\hline & $\begin{array}{l}\text { Slump } \\
\text { Flow }\end{array}$ & $\begin{array}{c}\text { Slump } \\
\text { Flow } \mathrm{T}_{50 \mathrm{~cm}}\end{array}$ & $\begin{array}{c}\text { V-Funnel } \\
\mathrm{T}_{0}\end{array}$ & $\begin{array}{c}\text { V-Funnel } \\
\mathrm{T}_{5 \min }\end{array}$ & $\begin{array}{c}\text { L-Box } \\
\left(\mathrm{H}_{2} / \mathrm{H}_{1}\right)\end{array}$ & J-Ring & $\begin{array}{c}\text { GTM } \\
\text { Screen } \\
\text { Stability }\end{array}$ & $\begin{array}{c}\text { Air } \\
\text { Content }\end{array}$ \\
\hline & $(\mathrm{mm})$ & (Sec.) & (Sec.) & (Sec.) & Ratio & $(\mathrm{mm})$ & $\%$ & $\%$ \\
\hline $\mathrm{A}$ & 670 & 3 & 10 & 12 & 0.8 & 10 & 10 & 2.2 \\
\hline $\mathrm{B}$ & 700 & 3 & 7 & 9 & 0.88 & 8 & 8 & 2.0 \\
\hline $\mathrm{C}$ & 720 & 2 & 5 & 8 & 1.0 & 5 & 6 & 1.9 \\
\hline M1 & 660 & 6 & 11 & 15 & 0.92 & 7 & 2.2 & 3.0 \\
\hline M2 & 700 & 4 & 8 & 10 & 0.95 & 6 & 1.51 & 2.7 \\
\hline M3 & 710 & 3 & 7 & 9 & 0.96 & 5 & 1.42 & 2.6 \\
\hline M4 & 770 & 2 & 5 & 7 & 1.0 & 3 & 0.76 & 3.0 \\
\hline M5 & 750 & 4 & 7 & 9 & 0.97 & 5 & 1.54 & 2.8 \\
\hline M6 & 660 & 6 & 12 & 16 & 0.82 & 12 & 2.86 & 2.9 \\
\hline M7 & 740 & 3 & 6 & 8 & 0.98 & 4 & 0.93 & 2.5 \\
\hline M8 & 720 & 3 & 7 & 9 & 0.97 & 5 & 1.24 & 2.6 \\
\hline M9 & 670 & 5 & 10 & 14 & 0.90 & 8 & 2.34 & 2.8 \\
\hline M10 & 650 & 6 & 14 & 18 & 0.80 & 12 & 3.25 & 3.1 \\
\hline M11 & 680 & 5 & 12 & 15 & 0.87 & 10 & 2.61 & 3.0 \\
\hline M12 & 685 & 5 & 11 & 14 & 0.90 & 9 & 2.10 & 2.9 \\
\hline M13 & 720 & 4 & 7 & 9 & 0.96 & 5 & 1.52 & 2.6 \\
\hline M14 & 655 & 7 & 13 & 17 & 0.81 & 13 & 3.43 & 3.2 \\
\hline M15 & 720 & 4 & 7 & 9 & 0.96 & 5 & 1.32 & 2.6 \\
\hline M16 & 770 & 3 & 5 & 7 & 1.0 & 3 & 0.98 & 2.5 \\
\hline M17 & 700 & 4 & 8 & 10 & 0.95 & 6 & 1.51 & 2.7 \\
\hline M18 & 700 & 4 & 8 & 10 & 0.95 & 6 & 1.51 & 2.7 \\
\hline M19 & 700 & 4 & 8 & 10 & 0.95 & 6 & 1.51 & 2.7 \\
\hline M20 & 700 & 4 & 8 & 10 & 0.95 & 6 & 1.51 & 2.7 \\
\hline M21 & 695 & 5 & 10 & 14 & 0.92 & 7 & 1.86 & 2.8 \\
\hline M22 & 725 & 3 & 6 & 8 & 0.97 & 5 & 1.38 & 2.6 \\
\hline M23 & 750 & 3 & 5 & 7 & 1.0 & 4 & 0.91 & 2.4 \\
\hline M24 & 720 & 4 & 8 & 11 & 0.96 & 5 & 1.41 & 2.7 \\
\hline M25 & 745 & 3 & 5 & 7 & 0.98 & 4 & 0.97 & 2.5 \\
\hline M26 & 770 & 2 & 4 & 5 & 1.0 & 3 & 0.78 & 2.3 \\
\hline M27 & 710 & 4 & 7 & 10 & 0.95 & 5 & 1.47 & 2.6 \\
\hline M28 & 740 & 3 & 5 & 7 & 0.98 & 4 & 1.29 & 2.5 \\
\hline M29 & 765 & 2 & 4 & 6 & 0.99 & 4 & 0.91 & 2.5 \\
\hline M30 & 710 & 4 & 9 & 12 & 0.90 & 6 & 2.8 & 2.6 \\
\hline
\end{tabular}




\begin{tabular}{|l|c|c|c|c|c|c|c|c|}
\hline M31 & 730 & 3 & 7 & 10 & 0.92 & 5 & 1.9 & 2.4 \\
\hline M32 & 760 & 3 & 5 & 8 & 0.94 & 5 & 1.46 & 2.3 \\
\hline Acceptance Criteria for SCC As Per EFNARC Guidelines [10] \\
\hline Min. & 650 & 2 & 6 & $6+0$ & 0.8 & 0 & 0 \\
\hline Max. & 800 & 5 & 12 & $12+3$ & 1.0 & 10 & 15 & \\
\hline
\end{tabular}

\subsubsection{Effect of extra water ratio on the fresh state properties}

Table 3 shows the variation in extra water ratio from $(10 \%, 12 \%, 14 \%$, and $16 \%)$ for mixtures (M14, M2, M15, and M16)all the four mixtures showed almost good flowability and displayed a good resistance to segregation of (SCGC). Slump flow for every one of the mixtures was inside the (EFNARC) scope of 650-800 $\mathrm{mm}$.A greatest slump flow value of $770 \mathrm{~mm}$ was accomplished for a mixture having extra water ratio as $16 \%$,the flow of the concrete was increased up to $17.6 \%$, which may be attributed to the increase inpercentage water, leading to improve the flowability.

\subsubsection{Effect of coarse aggregate type on the fresh state properties}

Table 3 delineated that the aftereffects of aggregate types (crushed dolomite, natural gravel, and crushed granite) for mixtures (M2, M27, and M30) with fly ash content $400 \mathrm{Kg} / \mathrm{m}^{3}$, (M22, M28, and M31) with fly ash content $450 \mathrm{Kg} / \mathrm{m}^{3}$, and (M25, M29, and M32) with fly ash content $500 \mathrm{Kg} / \mathrm{m}^{3}$. V-funnel test at $\mathrm{T}_{0}$ for all mixtures was inside as far as possible given by (EFNARC); a minimum flow time of 4 seconds was recorded for mixtureM29 containingon natural gravel with fly ash content $500 \mathrm{Kg} / \mathrm{m}^{3}$. Therefore, the V-funnel flow time was diminished up to $44.4 \%$ that might be ascribed to the natural gravel that gives the most astounding bond with binder particles in light of the fact that the surface is smooth when contrasted with crushed dolomite and crushed granite, in this manner has given more firm, smoothness and flowability. From the test outcomes delineated in Table 3, which showed that the test aftereffects of fresh state for (SCGC) mixtures have given all the more good consequences of fresh concrete.

\subsection{Mechanical properties of SCGC}

\subsubsection{Compressive strength}

\subsubsection{Effect of coarse to fine aggregate ratio on the compressive strength}

Table 4 and Fig. 1outlined that the compressive strength of (SCGC) mixture containing on coarse to fine aggregate ratio as $(60 \%: 40 \%)$ for blend $\mathrm{M} 1$ is higher than the compressive strength of mixtures prepared with coarse to fine aggregate ratio were $55 \%: 45 \%$, and 50\%:50\%) for mixtures M2, and M3respectively, were by around $2.6 \%$, and $7.6 \%$ respectively, at 28 days age. This may be due to the increasing in coarse aggregate ratio lead to more hardness for blend, thus gives compressive strength higher than the other blends.

\subsubsection{Effect of alkaline solution to fly ash ratio on the compressive strength}

The compressive strength of self-compacting geopolymer concrete containing on alkaline solution to fly ash ratio of 0.5 for mixture M2 is higher than the compressive strength of the mixtures with alternate proportions were $(0.3$, and 0.4 ) for mixtures M10, and M11 respectively, by around $39.6 \%$, and $11.5 \%$ respectively, at 28 days age. As outlined in Table 4 and Fig. 2 this increasing of compressive strength was because of increase the liquid materials lead to quickly dissolution of the fly ash particles.

Table 4 Mechanical properties of test results for SCCand SCGC

\begin{tabular}{|c|c|c|c|c|c|c|c|c|}
\hline \multirow[t]{2}{*}{$\begin{array}{l}\text { Mix } \\
\text { Code }\end{array}$} & \multicolumn{4}{|c|}{$\begin{array}{l}\text { Compressive Strength } \\
(\mathrm{MPa})\end{array}$} & \multirow{2}{*}{$\begin{array}{c}\text { Splitting Tensile } \\
\text { Strength } \\
(\mathrm{MPa})\end{array}$} & \multirow{2}{*}{$\begin{array}{l}\text { Flexural Strength } \\
(\mathrm{MPa})\end{array}$} & \multirow{2}{*}{$\begin{array}{l}\text { Bond Strength } \\
(\mathrm{MPa}) \\
28 \mathrm{~d}\end{array}$} & \multirow{2}{*}{$\begin{array}{c}\begin{array}{c}\text { Modulus of } \\
\text { Elasticity } \\
(\mathrm{GPa})\end{array} \\
28 \mathrm{~d}\end{array}$} \\
\hline & $3 d$ & $7 d$ & $28 d$ & $91 \mathrm{~d}$ & & & & \\
\hline A & 20.6 & 25.6 & 36.3 & 40.9 & 3.2 & 5.1 & 7.3 & 26.4 \\
\hline B & 21.4 & 27.2 & 38.7 & 43.3 & 3.4 & 5.6 & 7.7 & 28.6 \\
\hline $\mathrm{C}$ & 23.3 & 28.8 & 41.2 & 45.8 & 3.7 & 5.9 & 8.3 & 30.2 \\
\hline M1 & 41.7 & 44.0 & 46.7 & 48.8 & 5.4 & 7.7 & 9.40 & 38.8 \\
\hline M2 & 41.2 & 43.3 & 45.5 & 47.5 & 5.2 & 7.5 & 9.30 & 37.5 \\
\hline M3 & 40.2 & 40.6 & 43.4 & 45.4 & 4.8 & 7.3 & 9.0 & 36.1 \\
\hline M4 & 35.4 & 36.7 & 38.6 & 40.7 & 4.5 & 6.4 & 8.10 & 31.5 \\
\hline M5 & 38.8 & 40.2 & 42.5 & 45.3 & 5.1 & 7.2 & 8.80 & 35.5 \\
\hline M6 & 42.4 & 44.3 & 46.8 & 48.9 & 5.3 & 7.9 & 9.50 & 38.5 \\
\hline M7 & 33.0 & 34.9 & 36.5 & 37.5 & 4.0 & 5.9 & 7.60 & 32.0 \\
\hline M8 & 38.3 & 39.4 & 41.3 & 42.6 & 4.9 & 6.9 & 8.40 & 34.5 \\
\hline M9 & 43.4 & 44.4 & 47.6 & 49.8 & 5.6 & 8.1 & 9.80 & 39.0 \\
\hline M10 & 30.2 & 31.3 & 32.6 & 33.7 & 3.7 & 5.3 & 6.80 & 27.4 \\
\hline M11 & 37.5 & 38.9 & 40.8 & 42.2 & 4.6 & 6.7 & 8.30 & 33.5 \\
\hline M12 & 39.6 & 40.8 & 43.3 & 45.2 & 5.2 & 7.4 & 8.90 & 35.9 \\
\hline M13 & 42.9 & 44.9 & 47.2 & 49.3 & 5.4 & 7.8 & 9.70 & 38.6 \\
\hline
\end{tabular}


Study on Properties of Self-Compacting Geopolymer Concrete

\begin{tabular}{|c|c|c|c|c|c|c|c|c|}
\hline M14 & 46.3 & 47.7 & 50.6 & 52.6 & 5.8 & 8.3 & 10.50 & 41.4 \\
\hline M15 & 36.6 & 37.2 & 39.5 & 40.8 & 4.5 & 6.4 & 8.20 & 32.9 \\
\hline M16 & 29.7 & 30.6 & 31.9 & 33.1 & 3.7 & 5.3 & 6.60 & 27.1 \\
\hline M17 & 38.8 & 40.1 & 42.4 & 44.2 & 4.9 & 6.8 & 8.70 & 35.0 \\
\hline M18 & 43.5 & 44.9 & 47.8 & 49.9 & 5.6 & 8.0 & 9.7 & 39.5 \\
\hline M19 & 39.6 & 41.0 & 43.3 & 44.9 & 4.9 & 7.1 & 8.95 & 35.8 \\
\hline M20 & 42.9 & 44.0 & 46.8 & 49.1 & 5.4 & 7.9 & 9.6 & 38.2 \\
\hline M21 & 44.0 & 43.2 & 45.6 & 47.4 & 5.4 & 7.7 & 9.40 & 37.7 \\
\hline M22 & 43.2 & 44.9 & 47.5 & 49.6 & 5.5 & 7.9 & 9.60 & 39.0 \\
\hline M23 & 44.3 & 46.3 & 48.9 & 51.1 & 5.6 & 8.2 & 10.20 & 40.2 \\
\hline M24 & 42.8 & 44.3 & 46.7 & 48.8 & 5.3 & 7.8 & 9.50 & 38.9 \\
\hline M25 & 44.2 & 45.9 & 48.6 & 50.7 & 5.6 & 8.2 & 9.90 & 40.5 \\
\hline M26 & 45.5 & 47.0 & 49.8 & 52.3 & 5.7 & 8.4 & 10.30 & 40.7 \\
\hline M27 & 37.3 & 38.6 & 40.5 & 42.2 & 4.6 & 6.7 & 8.30 & 33.9 \\
\hline M28 & 38.9 & 40.4 & 42.7 & 44.3 & 4.9 & 6.9 & 8.90 & 36.0 \\
\hline M29 & 39.4 & 41.1 & 43.2 & 45.2 & 5.0 & 7.2 & 8.95 & 36.4 \\
\hline M30 & 43.5 & 45.1 & 47.6 & 49.9 & 5.4 & 7.7 & 9.65 & 39.2 \\
\hline M31 & 44.7 & 46.4 & 49.1 & 51.2 & 5.7 & 8.3 & 10.10 & 41.0 \\
\hline M32 & 45.7 & 47.3 & 50.3 & 52.8 & 5.9 & 8.4 & 10.40 & 41.8 \\
\hline
\end{tabular}

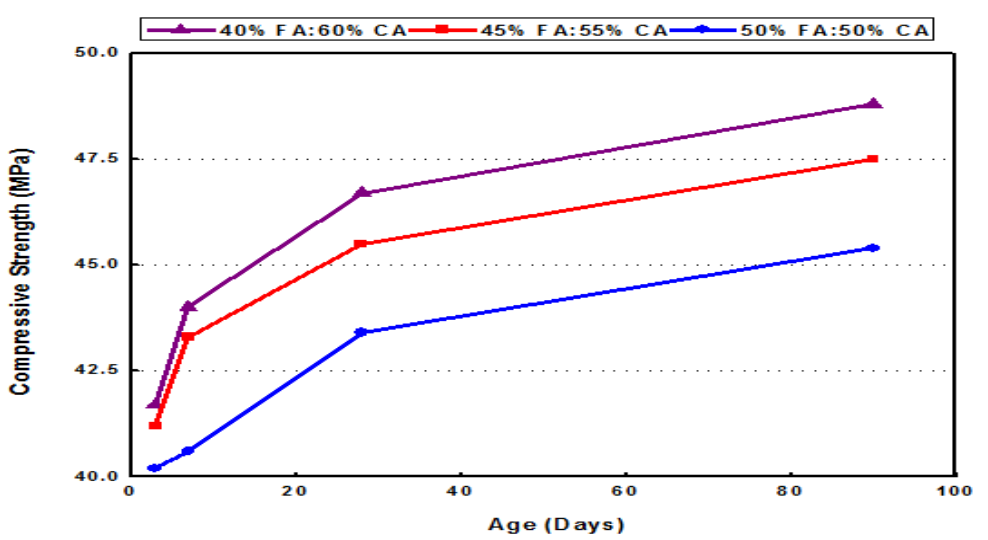

Fig. 1 Effect of coarse to fine aggregate ratio on the compressive strength of SCGC

\subsubsection{Effect of variation of SHS to SSS ratio on the compressive strength}

Table 4 and Fig. 3 outlined that the compressive strength of (SCGC) mixture containing on sodium hydroxidesolution (SHS) to sodium silicatesolution (SSS) proportion of (1:2.75) for mixture M6 is higher than the compressive strength of the mixtures with alternate proportions were $(1: 2,1: 2.25$, and 1:2.5) for mixtures (M4, M5, and M2) by around $21.2 \%, 10.1 \%$, and $2.9 \%$ respectively, at 28 days age. This increasing of compressive strength was because of sodium silicate activator, which breaks down quickly and fills the open porosity by gel when the fluid stage could reach and start to bond the fly powder particle giving an enhancement in compressive strength with the higher proportion of (SHS) to (SSS) which matches with B Tempest et al. [11].

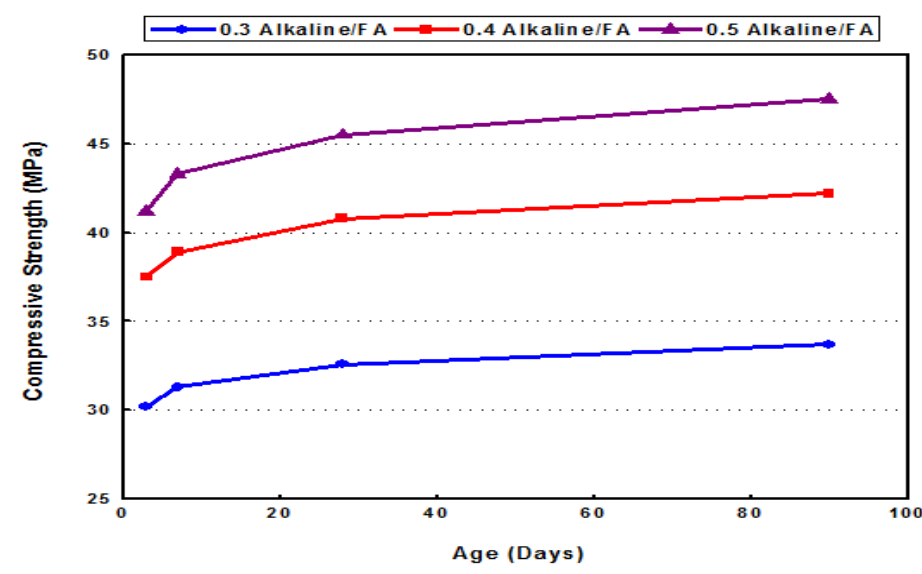

Fig. 2 Effect of alkaline solution to fly ash ratio on the compressive strength of SCGC 


\subsubsection{Effect of sodium hydroxide molarities on the compressive strength}

Table 4 and Fig. 4 demonstrates the compressive strength of (SCGC) mixture containing on 14M for blend $\mathrm{M} 9$ is higher than the compressive strength of mixtures prepared with $8 \mathrm{M}, 10 \mathrm{M}$, and $12 \mathrm{M}$ for mixtures M7, M8, and M2, were by around $30.4 \%, 15.3 \%$, and $4.6 \%$ respectively, at 28 days age. The expansion in the sodium hydroxide molarity prompted more dissolution of the solid materials and built geopolymerization response and henceforth, higher compressive strength which matches with J.Temuujin et al. [12].

\subsubsection{Effect of fly ash content on the compressive strength}

Table 4 and Fig. 5 represented that the compressive strength of (SCGC) mixture containing on fly ash contents were $\left(400,450\right.$, and $\left.500 \mathrm{Kg} / \mathrm{m}^{3}\right)$ as (M13, M23, and M26) with $7 \%$ superplasticizer dose and crushed dolomite is higher than the strength of mixtures (M12, M21, and M24) and (M2, M22, and M25) which increment by around (6.6\% to $9.0 \%)$ and (2.5\% to $3.7 \%$ ) of mixtures containing on 5\%, and 6\% superplasticizer dose and crushed dolomite respectively, at 28 days age. This was because of the more compelling activity of the superplasticizer with fly ash content in expanding the fresh state of the mixture. Pores and micro-cracks were seen at lower SP dosages and fly ash content that could bring about decrease in the compressive strength. This corresponds with Muhd Fadhil Nuruddin et al. [13].

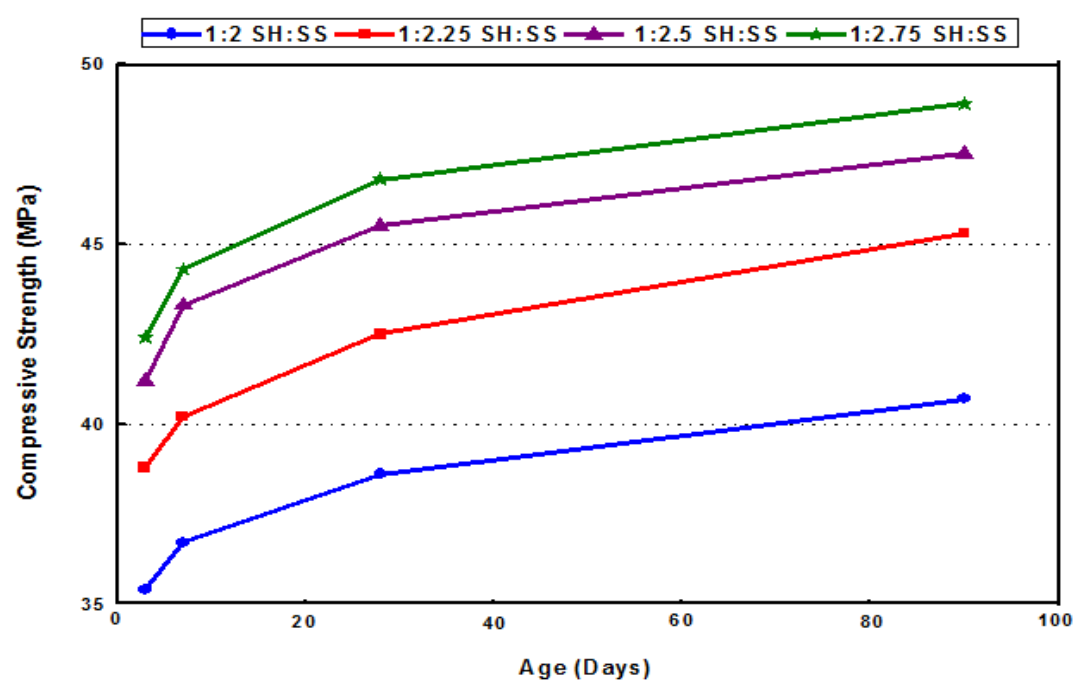

Fig. 3 Effect of variation of SHS to SSS ratio on the compressive strength of SCGC

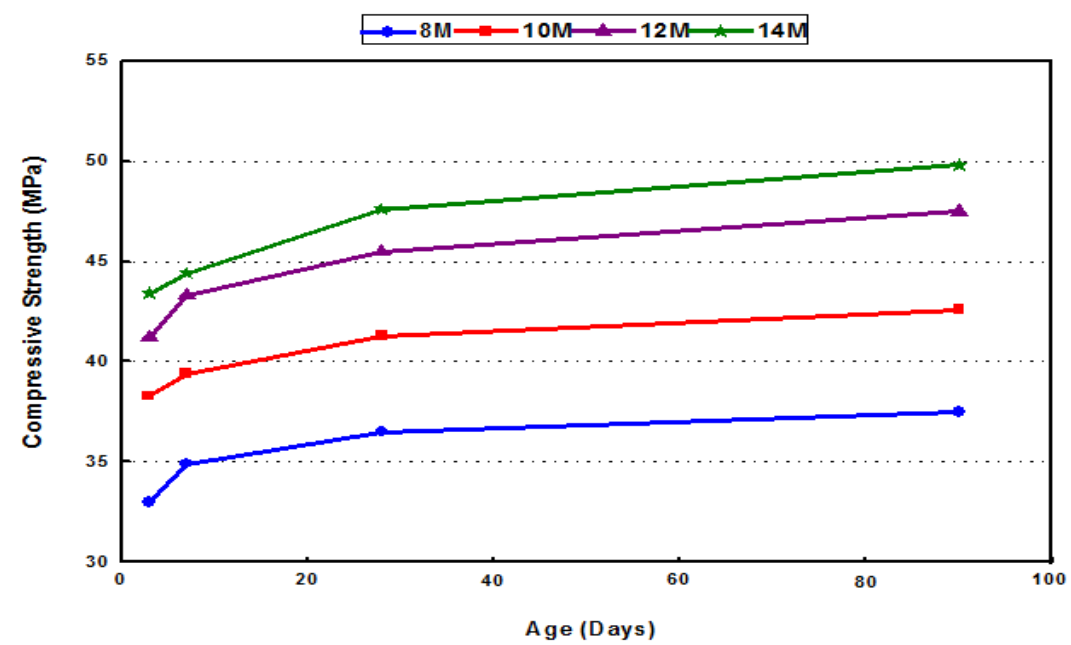

Fig. 4 Effect of sodium hydroxide molarities on the compressive strength of SCGC 


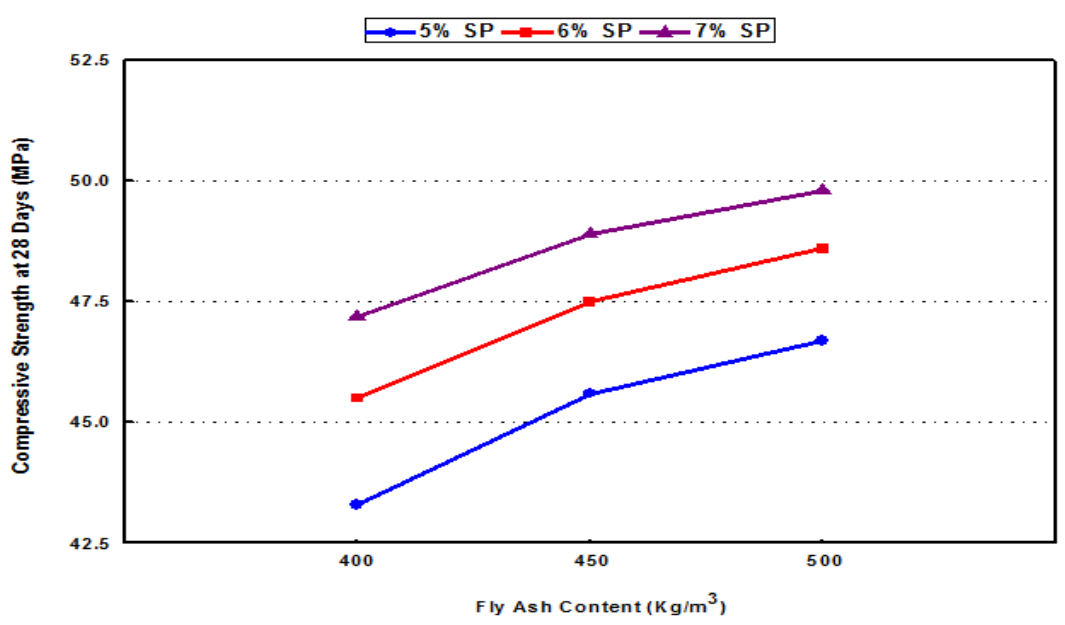

Fig. 5 Effect of fly ash content on the compressive strength of SCGC with dolomite

\subsubsection{Effect of curing time on the compressive strength}

Table 4 and Fig. 6 outlined that the compressive strength of (SCGC) mixture which cured in the oven at a temperature of $70{ }^{\circ} \mathrm{C}$ for a time of 72 hours for mixture M18 is higher than the compressive strength of mixtures cured in the oven at a temperature of $70{ }^{\circ} \mathrm{C}$ for 24 , and 48 hours. The upgrade in compressive quality for mixtures M17, and M2, was by around $12.7 \%$ and $5.1 \%$, respectively, at 28 days age. This can be ascribed to the more extended curing time that prompts the change of geopolymerization process giving higher coming about compressive strength.

\subsubsection{Effect of curing temperature on the compressive strength}

Keeping in mind the end goal to concentrate the effect of curing temperature on the compressive strength of (SCGC) mixtures M19, M2, and M20 were prepared. Except temperature, the various test parameters were kept steady. In this study, the curing temperatures were changed from $\left(60^{\circ} \mathrm{C}, 70^{\circ} \mathrm{C}\right.$, and $\left.80^{\circ} \mathrm{C}\right)$. From Table 4 and Fig. 7 it was observed that blend M20, which cured at $80^{\circ} \mathrm{C}$, for a time of 48 hours, created an upgrade of the compressive strength contrasted with mixtures, which cured at $60^{\circ} \mathrm{C}$ and $70^{\circ} \mathrm{C}$, by around $8.1 \%$ and $2.9 \%$,respectively, at 28 days age. This upgrade was because of the high curing temperature, which in part, prompts a snappier geopolymerization prepare that quickens the hardening of self-compacting geopolymer concrete.

\subsubsection{Effect of coarse aggregate type on the compressive strength}

It can be seen from Table 4 and Fig. 8 that the compressive strength for mixtures containing on crushed granite of mixtures (M30, M31, and M32) with 6\% superplasticizer dose and fly ash contents were (400, 450, and $500 \mathrm{Kg} / \mathrm{m}^{3}$ ) is higher than the compressive strength of mixtures arranged with natural gravel and crushed dolomitewere (M27, M28, and M29) and (M2, M22, and M25) at the same superplasticizer dosage and fly ash contents by around $(17.5 \%, 15.0 \%$, and $16.4 \%)$ and $(4.6 \%, 3.4 \%$, and $3.5 \%)$, respectively, at 28 days age. This might be because of the crushed granite was more hardness, subsequently gives compressive strength higher than the natural gravel and crushed dolomite.

\subsubsection{Effect of extra water ratio on the compressive strength}

It can be observed from Table 4 and Fig. 9 that the compressive strength of (SCGC) mixture containing on $10 \%$ extra water for blend M14 is higher than the compressive strength of mixtures prepared with $12 \%, 14 \%$, and $16 \%$ extra waterfor blends M2, M15, and M16, were by around $11.2 \%, 28.1 \%$, and $58.6 \%$ respectively, at 28 days age. This may be attributed to the increase in percentage extra water, subsequently leading to the increasing in voids ratio for blendafter hardening that could cause reduction in the compressive strength.

In the earlier form test results illustrates in Table 4 it was observed that test results of compressive strength for self-compacting geopolymer concrete (SCGC) mixtures given good results if compared to the self-compacting concrete (SCC) mixtures with Portland cement. 


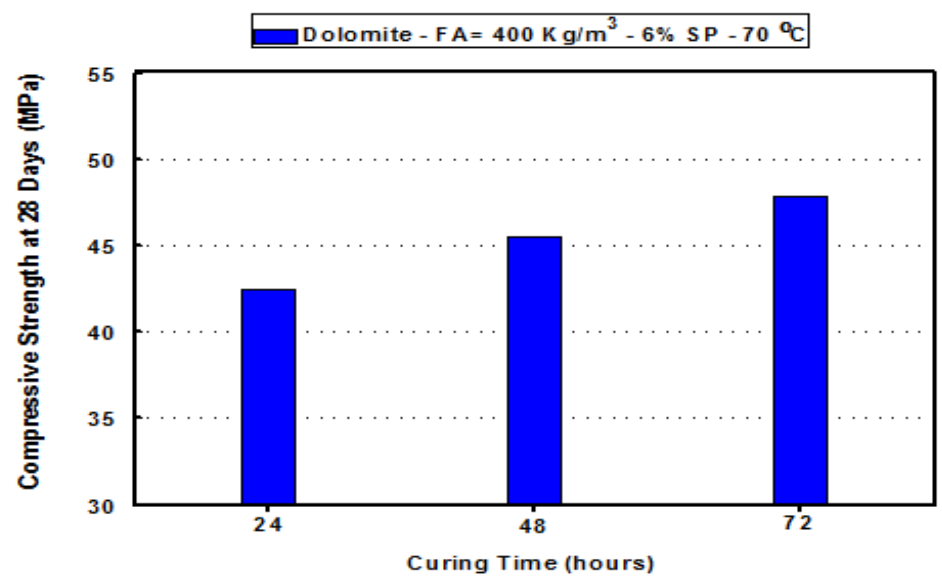

Fig. 6 Effect of curing time on the compressive strength of SCGC

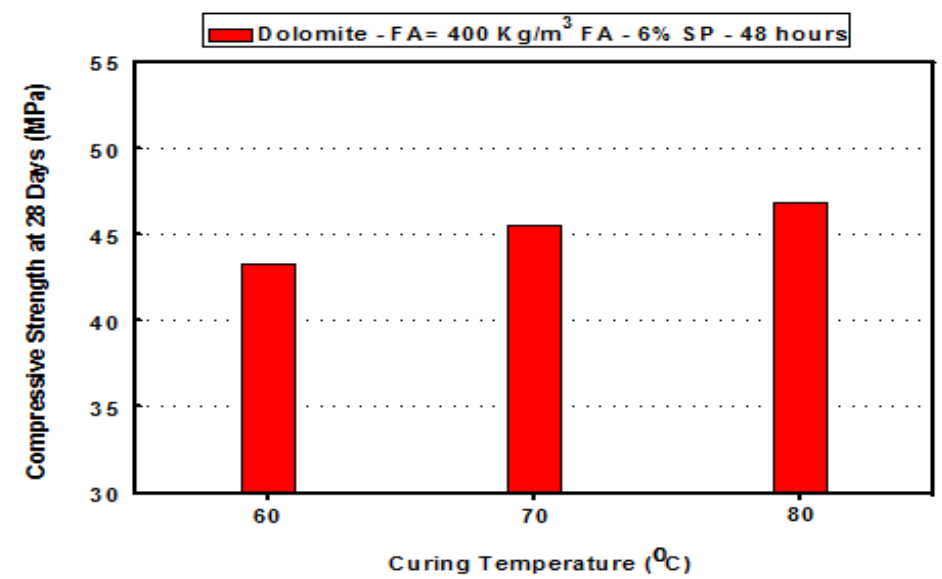

Fig. 7 Effect of curing temperature on the compressive strength of SCGC

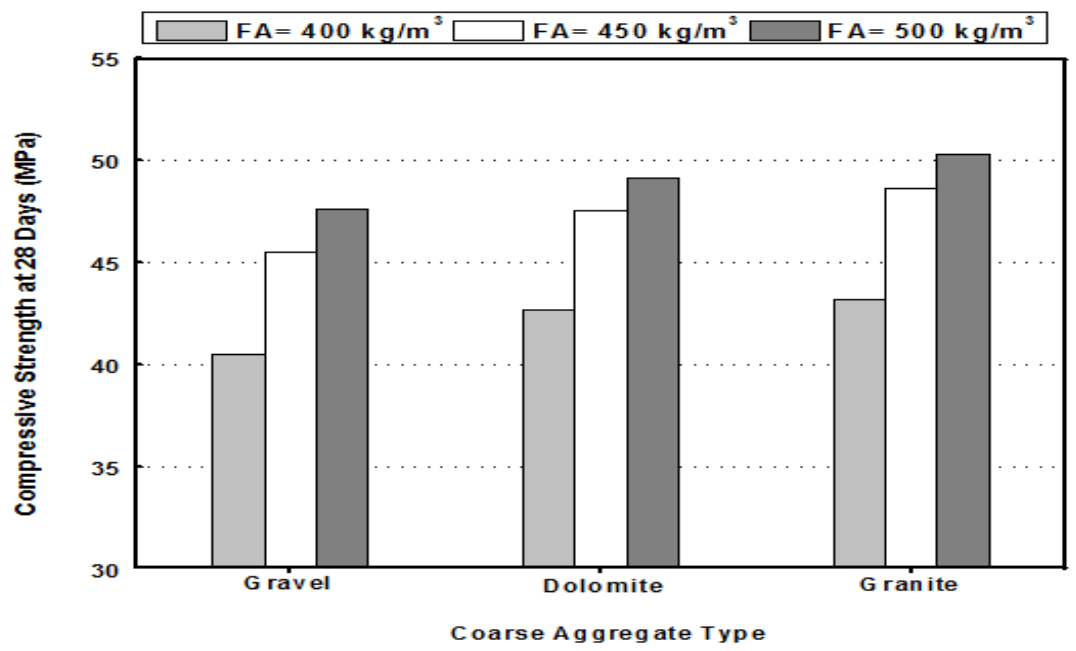

Fig. 8 Effect of coarse aggregate type on the compressive strength of SCGC 


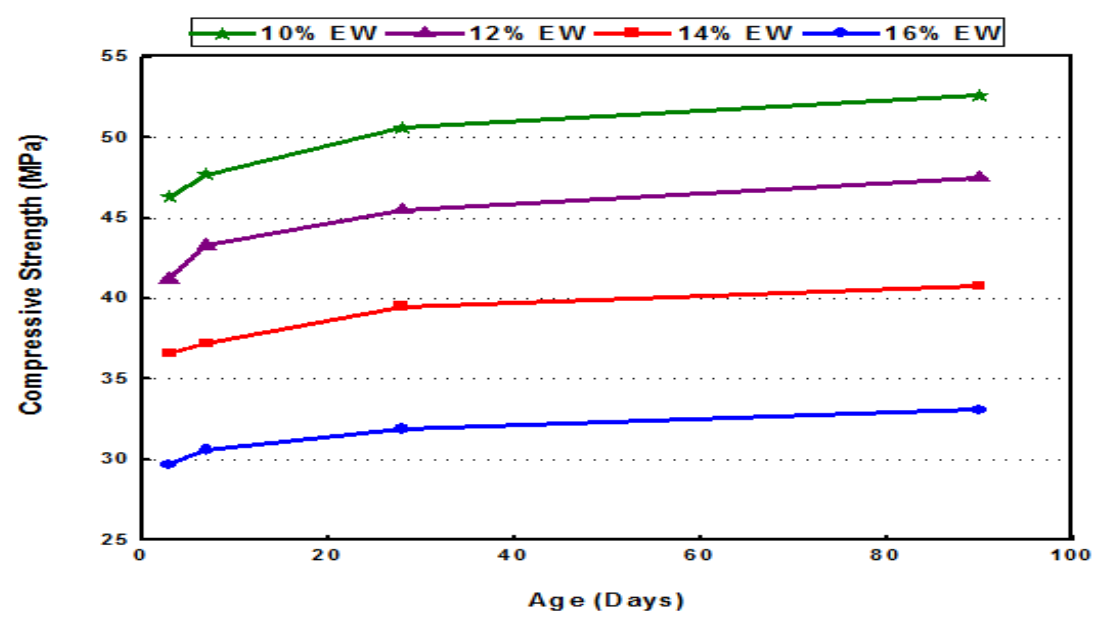

Fig. 9 Effect of extra water ratio on the compressive strength of SCGC

\subsubsection{Splitting tensile strength}

The test results of splitting tensile strength for 32 different SCGC mixtures are shown in Table 4 and Fig. 10. The 28-days splitting tensile strength of SCGCranged from 3.7 to $5.9 \mathrm{MPa}$, the average value of splitting tensile strength is about $11.5 \%$ from compressive strength. The analysis of test results yields the following relationfor predicting the splitting tensile strength: $\left(f_{\mathrm{sp} 28}=0.1184 f_{\mathrm{c} 28}-0.1392\right)$.

\subsubsection{Flexural strength}

Table 4 and Fig. 11show the results of flexural strength for 32 different SCGC mixtures ranged from 5.3 to $8.4 \mathrm{MPa}$, the average value offlexural strength is about $16.6 \%$ from compressive strength. Also, it appeared that the relation between experimental results of flexural strength and compressive strength is independent of the 28-days agewas : $\left(f_{28}=0.1756 f_{\mathrm{c} 28}-0.4144\right)$.

\subsubsection{Bond strength}

The 28-days bond strengthfor 32 different SCGC mixtures ranged from 6.6 to $10.5 \mathrm{MPa}$, as shown in Table 4. The average value of bond strength is about $20.6 \%$ from compressive strength. The relation between bond strength and compressive strength is independent of the 28-days age was : $\left(f_{\mathrm{b} 28}=0.1993 f_{\mathrm{c} 28}+0.277\right)$, as shown in Fig. 12.

\subsubsection{Modulus of elasticity}

The measurement of the modulus of elasticity for 32 different SCGC mixtures. The compressive strength of these mixtures from 31.9 to $50.6 \mathrm{MPa}$, as shown in Table 4. Also, the measured modulus of elasticity ranges from 27.1 to $41.8 \mathrm{GPa}$, the relation between modulus of elasticity and compressive strength is independent of the 28-days age was : $\left(\mathrm{E}_{\mathrm{c} 28}=0.7729 f_{\mathrm{c} 28}+2.4947\right)$, as shown in Fig. 13.

\subsection{Physical properties of SCGC \\ 3.3.1 Permeability}

To evaluate the water permeability of concrete, the apparatus subjects the concrete specimens to a hydrostatic water pressure of 30 bars for a 24 hours period. Table 5 shows the coefficient of permeability for 16 different SCGC and SCC mixtures. The coefficient of permeability for different SCGC mixtures ranged from $0.7 \times 10^{-11}$ to $1.48 \times 10^{-11}$, the coefficient of permeability of SCGC can be reduced, because the microstructure of SCGC denser. Whereas the coefficient of permeability values of mixtures prepared with SCC was $0.67 \times 10^{-11}$, $0.51 \times 10^{-11}$, and $0.47 \times 10^{-11} \mathrm{~cm} / \mathrm{sec}$ respectively (mixtures No; A, B, and C). It can be observed that the coefficient of permeability decreases as the cement content increases. Fig. 14 indicate that the higher of test results ofpermeability for 13 different SCGCmixtures may adversely affect its compressive strength, this can be attributed to found the internal pores, consequently this leads to reduction in the microstructure of SCGC denser and compressive strength.

\subsubsection{Water absorption}

To determine the water absorption of the specimens, three cubes from each series were taken after curing at a temperature of $60{ }^{\circ} \mathrm{C}$ for 24 hours, and all specimens were then stored in room temperature prior to testing, and their weights were determined as initial weights. The samples were then immersed in water for 24 hours and their saturated surface dry weights were recorded as the final weights. Water absorption of specimens is reported as the percentage of weight increases. The temperature was kept under $60^{\circ} \mathrm{C}$ to avoid any change in the structural configuration which may be caused due to the exposure to a temperature over the curing one. The 
test results of water absorption for 16 different SCGC and SCC mixtures are shown in Table 5.From Fig.15 it was observed that the increasing of test results ofwater absorption for 13 different SCGCmixtures may adversely affect its compressive strength such as thepermeability. The water absorption for different SCGC mixtures ranged from $2.24 \%$ to $3.01 \%$. Whereas the water absorption values of mixtures prepared with SCC was $2.0 \%$, $1.86 \%$, and $1.75 \%$ respectively (mixtures No; $\mathrm{A}, \mathrm{B}$, and C).

\subsubsection{Drying shrinkage}

Table 5 and Fig. 16demonstrate the plots of drying shrinkage strain versus age in days for the heat cured test specimens. It can be seen that SCGC undergoes very low drying shrinkage compared to that of SCC with ordinary Portland cement. The final value of drying shrinkage strain after 91 days period was only around 118 microstrain. In SCGC mixtures, most of the water released during the chemical reaction may evaporate during the curing process, because the remaining water contained in the micro-pores of the hardened concrete is small, the induced drying shrinkage is also very low.

Table 5 Physical properties of test results for SCCand SCGC

\begin{tabular}{|c|c|c|c|c|c|c|c|c|c|}
\hline \multirow[t]{2}{*}{$\begin{array}{l}\text { Mix } \\
\text { Code }\end{array}$} & $\begin{array}{l}\text { Coefficient of Permeability, } \\
\mathrm{K}^{*} 10^{-11}(\mathrm{~cm} / \mathrm{sec})\end{array}$ & Water Absorption \% & \multicolumn{7}{|c|}{ Drying Shrinkage (micro strain) } \\
\hline & $28 \mathrm{~d}$ & $28 \mathrm{~d}$ & $3 \mathrm{~d}$ & $7 d$ & $14 d$ & $21 \mathrm{~d}$ & $28 \mathrm{~d}$ & $56 \mathrm{~d}$ & $91 \mathrm{~d}$ \\
\hline $\bar{A}$ & 0.67 & 2.0 & 80 & 175 & 230 & 290 & 305 & 395 & 450 \\
\hline B & 0.51 & 1.86 & 90 & 190 & 270 & 305 & 325 & 420 & 480 \\
\hline $\mathrm{C}$ & 0.47 & 1.75 & 95 & 198 & 285 & 315 & 340 & 435 & 490 \\
\hline M2 & 1.04 & 2.53 & 35 & 55 & 62 & 69 & 78 & 86 & 105 \\
\hline M4 & 1.35 & 2.92 & 28 & 48 & 56 & 63 & 73 & 80 & 93 \\
\hline M5 & 1.13 & 2.71 & 32 & 52 & 59 & 66 & 75 & 83 & 98 \\
\hline M6 & 0.87 & 2.45 & 40 & 60 & 65 & 74 & 80 & 90 & 110 \\
\hline M7 & 1.48 & 3.01 & 31 & 51 & 58 & 65 & 74 & 81 & 100 \\
\hline M8 & 1.05 & 2.75 & 33 & 54 & 60 & 67 & 76 & 84 & 102 \\
\hline M9 & 0.78 & 2.32 & 40 & 59 & 65 & 73 & 81 & 90 & 109 \\
\hline M17 & 1.13 & 2.65 & 44 & 63 & 68 & 77 & 87 & 98 & 118 \\
\hline M18 & 0.75 & 2.30 & 30 & 51 & 60 & 66 & 73 & 82 & 98 \\
\hline M22 & 0.77 & 2.32 & 40 & 60 & 67 & 73 & 83 & 90 & 110 \\
\hline M25 & 0.70 & 2.25 & 44 & 64 & 72 & 79 & 90 & 96 & 117 \\
\hline M28 & 1.12 & 2.62 & 37 & 56 & 61 & 70 & 80 & 88 & 107 \\
\hline M31 & 0.70 & 2.24 & 35 & 54 & 62 & 68 & 77 & 84 & 103 \\
\hline
\end{tabular}

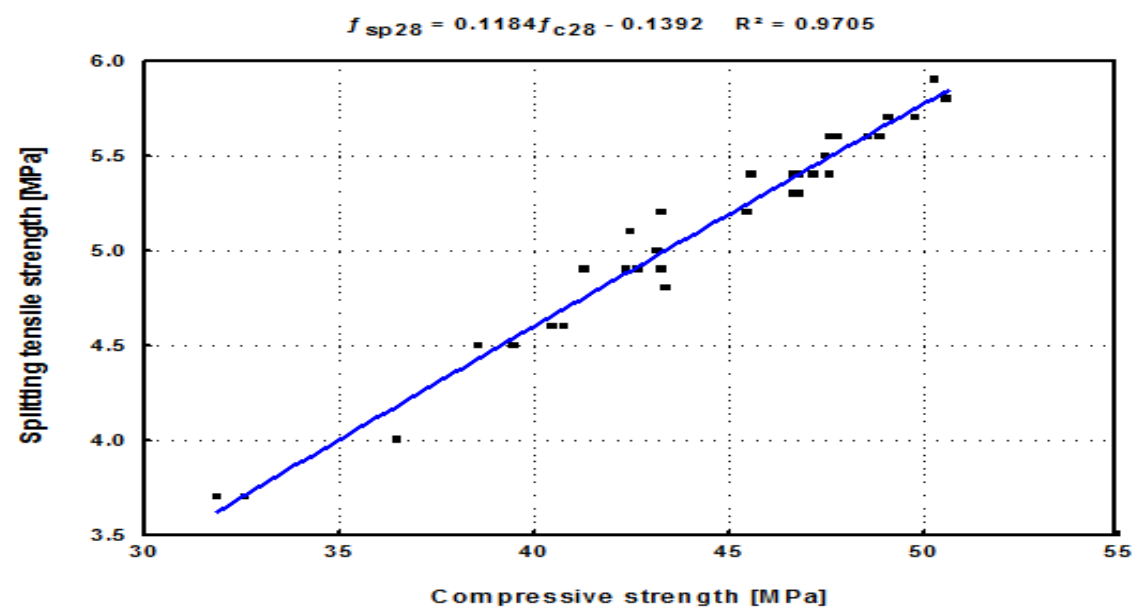

Fig. 10Splitting tensile strength versus compressive strength of SCGC 


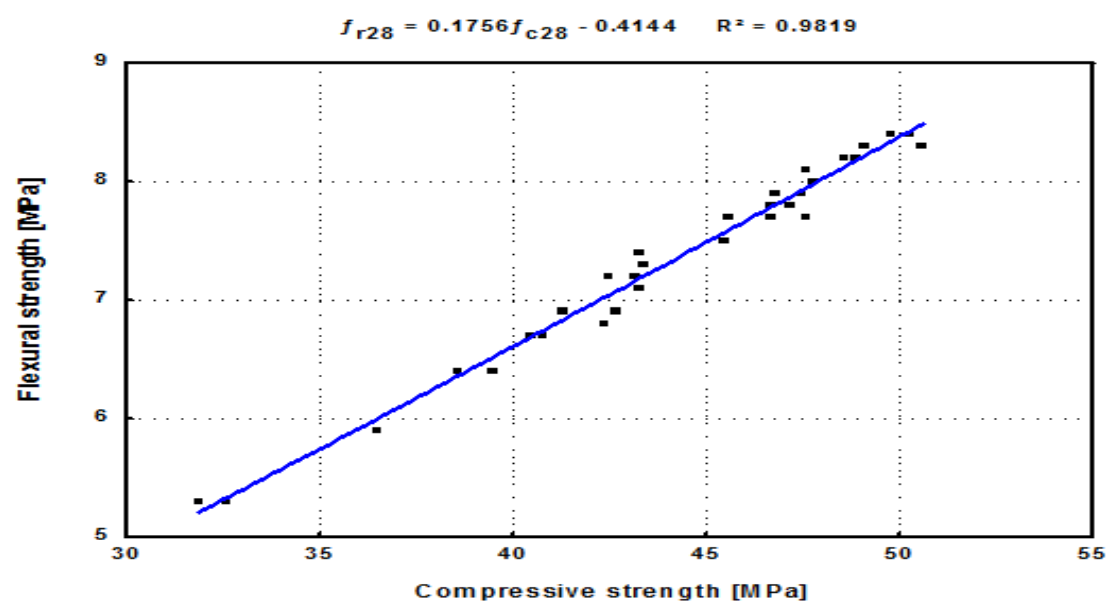

Fig. 11Flexural strength versus compressive strength of SCGC

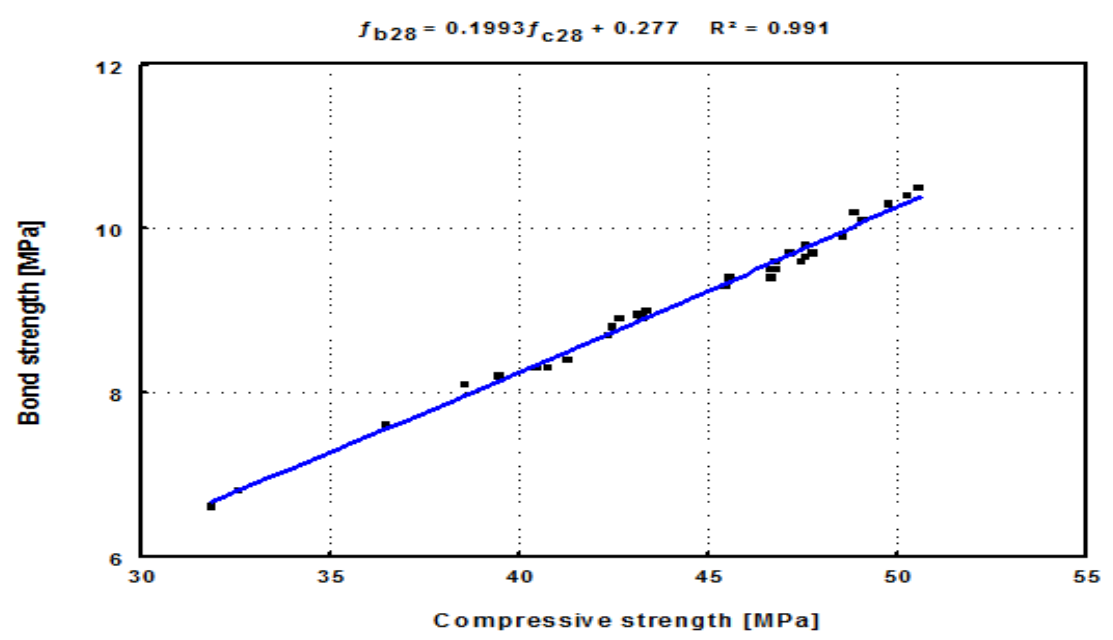

Fig. 12 Bond strength versus compressive strength of SCGC

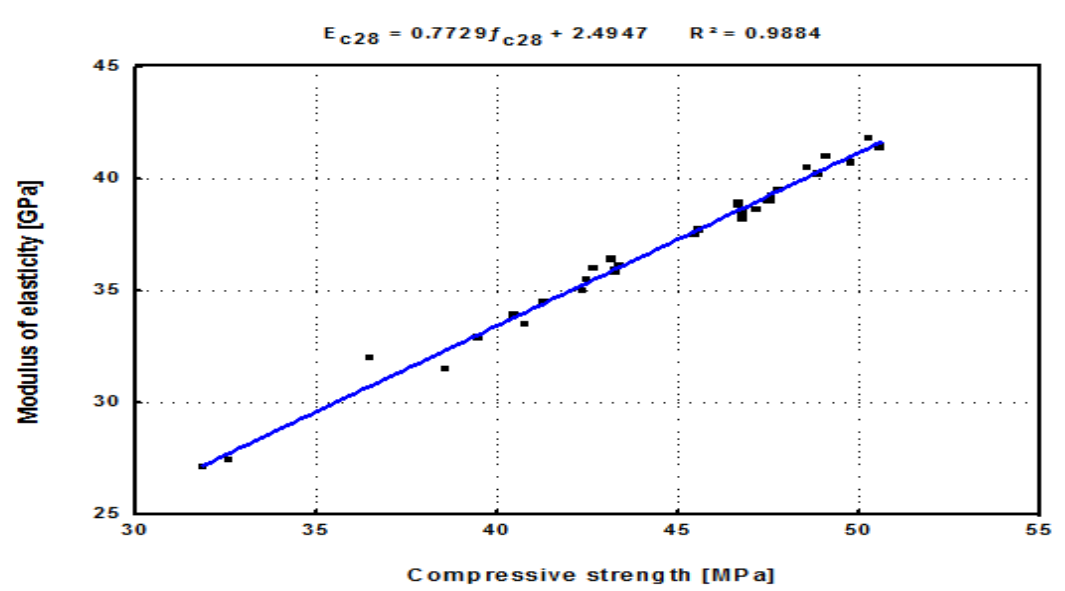

Fig. 13Modulus of elasticity versus compressive strength of SCGC 


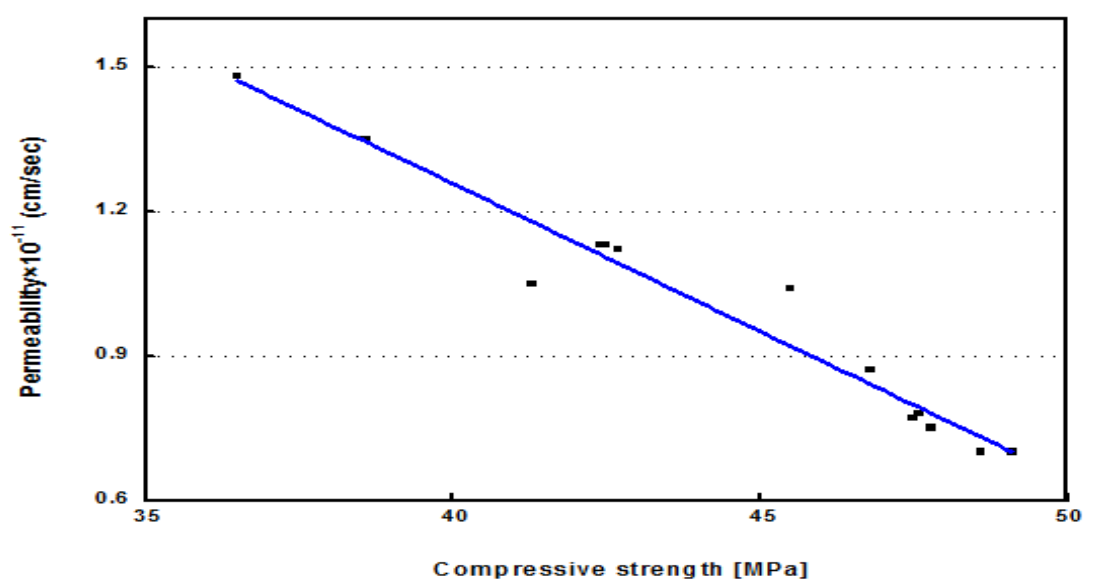

Fig. 14 Permeability versus compressive strength of SCGC

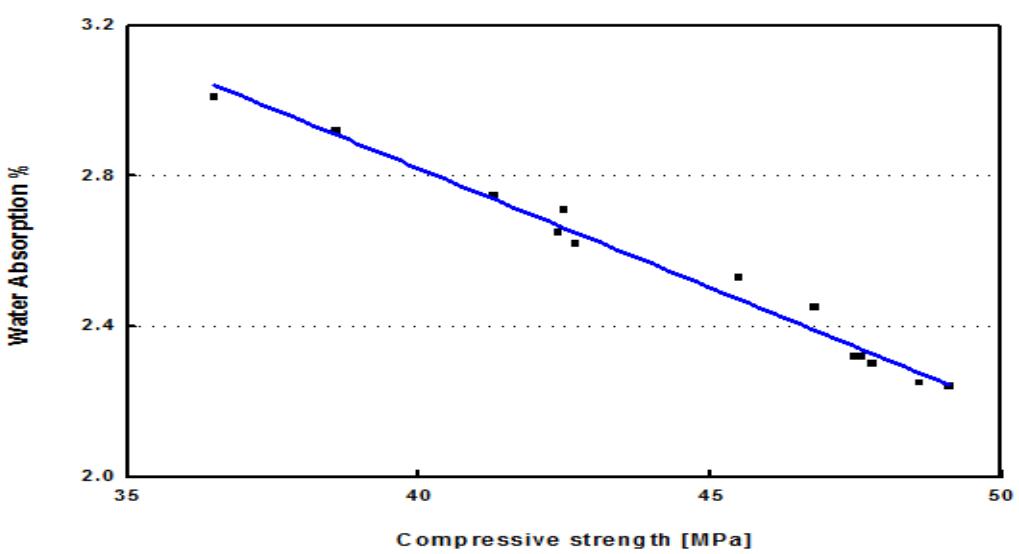

Fig. 15Water absorption versus compressive strength of SCGC

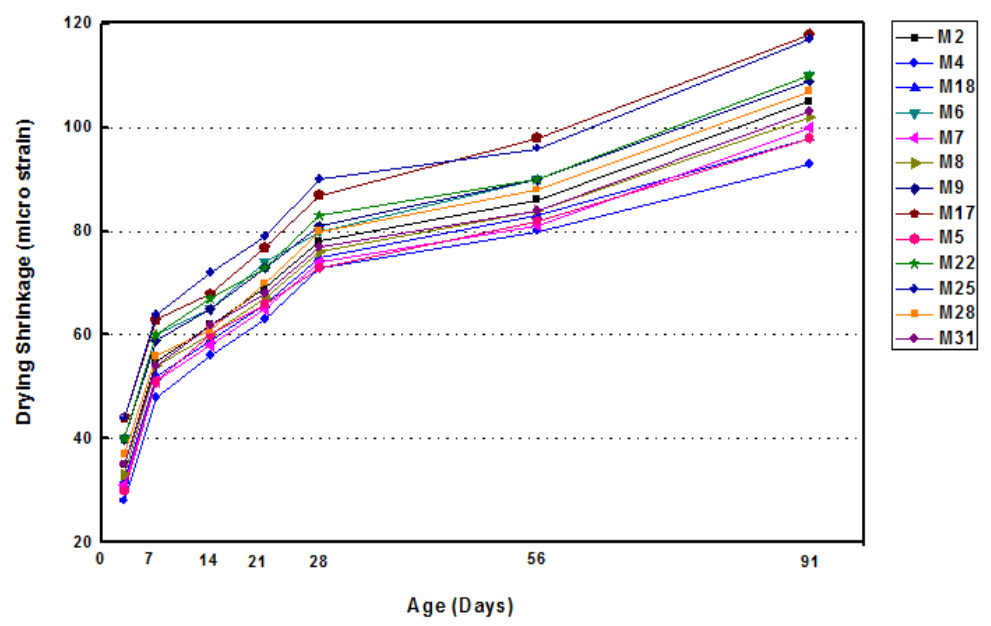

Fig. 16 Drying shrinkage of SCGC 


\section{Conclusions}

From the analysis and discussion of test results obtained from this research, the following conclusions can be drawn:

1. Use of fly ash based self-compacting geopolymer concrete as an alternative binder can help reduce $\mathrm{CO}_{2}$ emission of concreteas compared to ordinary Portland cement.

2. The fresh state tests comes about demonstrate that an expansion in the molarity of sodium hydroxide between $8 \mathrm{M}$ to $14 \mathrm{M}$ expanded the viscosity and cohesiveness of SCGC mixtures.

3. Utilizing fly ash contents in (SCGC) mixtures from $400 \mathrm{Kg} / \mathrm{m}^{3}$ to $500 \mathrm{Kg} / \mathrm{m}^{3}$, enhanced the compressive strength of self-compacting geopolymer concrete (SCGC) especially when superplasticizer dosages increased.

4. Longer curing time between 24 to 72 hours at a temperature of $70^{\circ} \mathrm{C}$ enhances the geopolymerization procedure bringing about higher compressive strength at early ages.

5. Higher value of compressive strength for SCGC reached to $52.8 \mathrm{MPa}$ at age 91 days.

6. The mechanical properties of SCGC are only a fraction of the compressive strength, as in the case of SCC with Portland cement.

7. Heat-cured SCGC undergoes very low drying shrinkage compared to that of SCC with ordinary Portland cement.

8. The permeability and water absorption of the hardened SCGC decrease with the increase in compressive strength of the SCGC.

\section{References}

[1]. M. Fareed Ahmed, M. Fa dhil Nuruddin, andNasir Sha fiq, Compressive strength and workability characteristics of low-calcium fly ashbased self-compacting geopolymer concrete, World Aca demy of Science Engineering and Technology, Vol: 5, 2011, PP. 8-14.

[2]. Joseph Davidovits, J, Global Waming Impact on the Cement and Aggregates Industries, World Resource Review, Vol. 6, No.2, 1994, PP. 263-278.

[3]. D. Hardjito, S. E. Wallah, Dody M. J. Sumajouw, andB.V. Rangan, On the Development of Fly Ash-Based Geopolymer Concrete, ACI Materials Joumal, Vol, No.101, 2004, PP. 467-472.

[4]. Fareed Ahmed Memon, Muhd Fadhil Nuruddin, Samuel Demie, and Nasir Shafiq, Effect of superplasticizer and extra water on workability and compressivestrength of self-compacting geopolymer concrete, Research Joumal of Applied Sciences, Engineering and Technology, Vol. 4, No.2, 2012, PP. 407-414.

[5]. Muhd Fadhil Nuruddin, Samuel Demie, andNasir Shafiq, Effect of mix composition on workability and compressive strength of selfcompacting geopolymer concrete, Can J Civil Eng. NRC Res Press, Vol. 38, 2011, PP. 1-8.

[6]. Mohamed Omar, Production of high performance geopolymer concrete (green concrete), PhD. Thesis, Suez University, 2015.

[7]. ASTM C618 Class F, Standard specification for coal fly ash and raw or calcined natural pozzolan for use in concrete.

[8]. ESS (4756-1/2009) Egyptian Standard Specifications, cement physical and mechanical test.

[9]. ESS (1109/2002) Egyptian Standard Specifications, concrete aggregates from natural sources.

[10]. EFNARC (2002) Specification and Guidelines for Self-Compacting Concrete.

[11]. B Tempest, O Sanusi, J Gergely, V Ogunro and D Weggel, Compressive strength and embodied energy optimization of fly ash based geopolymer concrete, World of Coal Ash Conference in Ed., Lexington, KY, USA, 2009, PP. 1-17.

[12]. Temuujin J, Williams R.P, van Riessen, A, Effect of mechanical activation of fly ash on the properties of geopolymer cured at ambient temperature, Joumal of Materials Processing Technology, 2009, PP. 5276-5280.

[13]. Nuruddin MF, Kusbiantoro A, Qazi S, Shafiq N, Compressive strength and interfacial transition zone characteristic of geopolymer concrete with different cast in-situ curing condition, World Aca demy of Science, Engineering and Technology, Intemational Joumal of Environmental, Chemical, Ecological, Geological and Geophysical Engineering, Vol .5, No. 1, 2011, PP. 51-54. 